\title{
Observations of erosion on valley fills produced by mountaintop removal coal mining
}

Miles Reed and Dr. Steve Kite

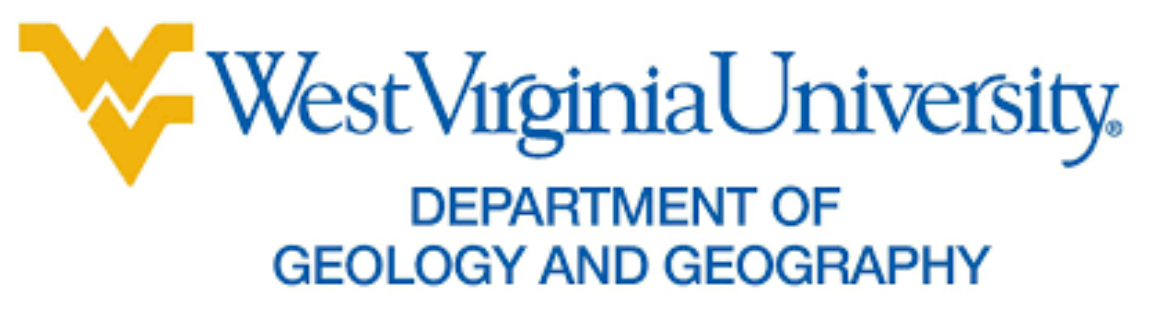




\section{Acknowledgements}

I would like to thank Dr. Steve Kite (advisor @ WVU), Dr. Tom Coulthard (University of Hull), Dr. Chris Ryan (WVDNR), Mr. Nick Schaer (WVDEP), The Greater Kanawha Valley Foundation, and The Geological Society of America.
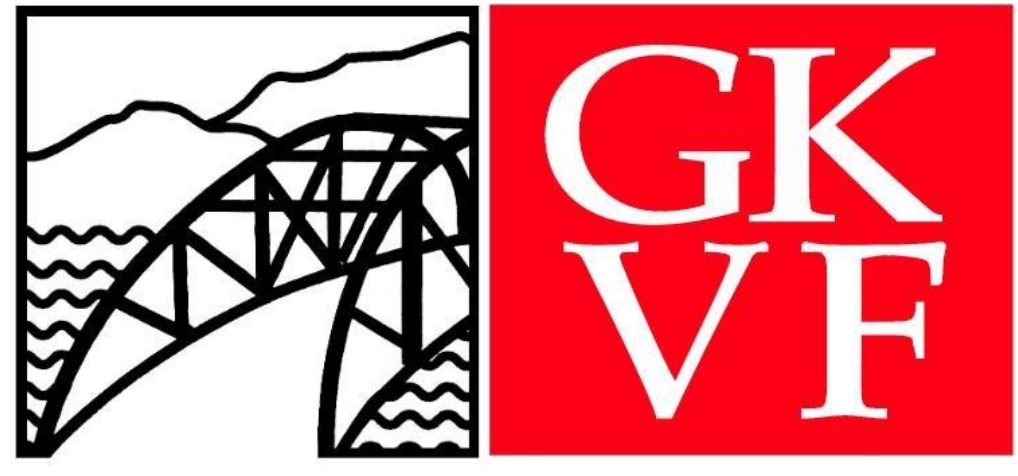

https://tgkvf.org/wp-content/uploads/2016/04/GKVF-logo-with-bridge.jpg

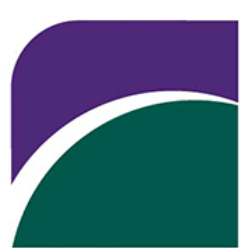

THE GEOLOGICAL SOCIETY OF AMERICA ${ }^{\circledR}$ 
- Tops of mountains removed with explosives to mine underlying coal seams

- Geologic materials increase in volume during mining

- Adjacent valleys filled with excess materials

- Regulated under the Surface Mine Control and Reclamation Act (SMCRA) (EPA, 2011)

\section{Former}

Mountain Contour
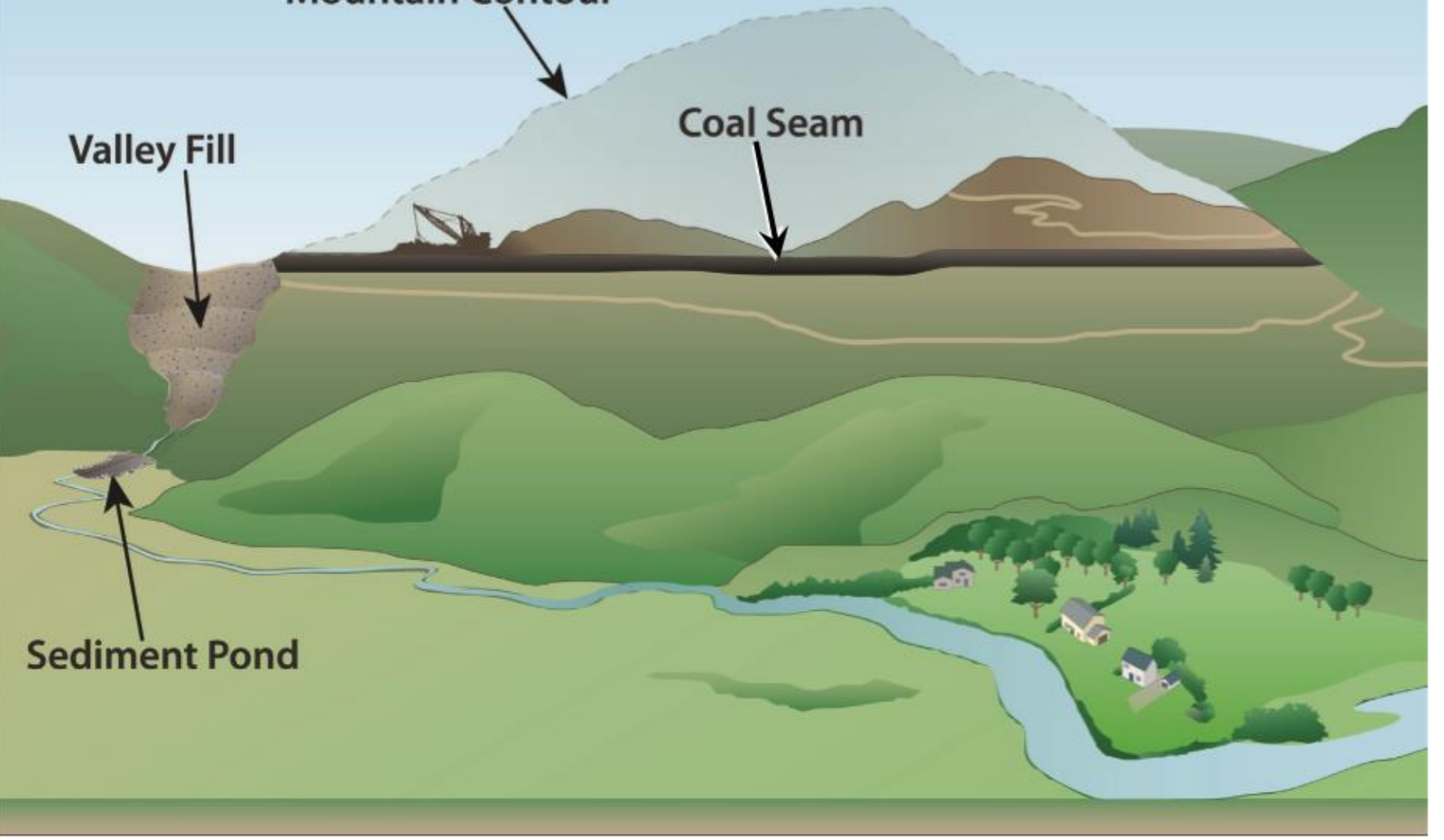
- Graded and compacted with heavy machinery

- Terraces limit slope length

- Boulder-lined drains act as ephemeral channels

- Drains can also be along the edge of the face and side slope (groin drain)

- No required maintenance after full reclamation

(Michael et al., 2010)

Landform elements of anthropogenic valley fill All lidar data from TAGIS (tagis.dep.wv.gov)

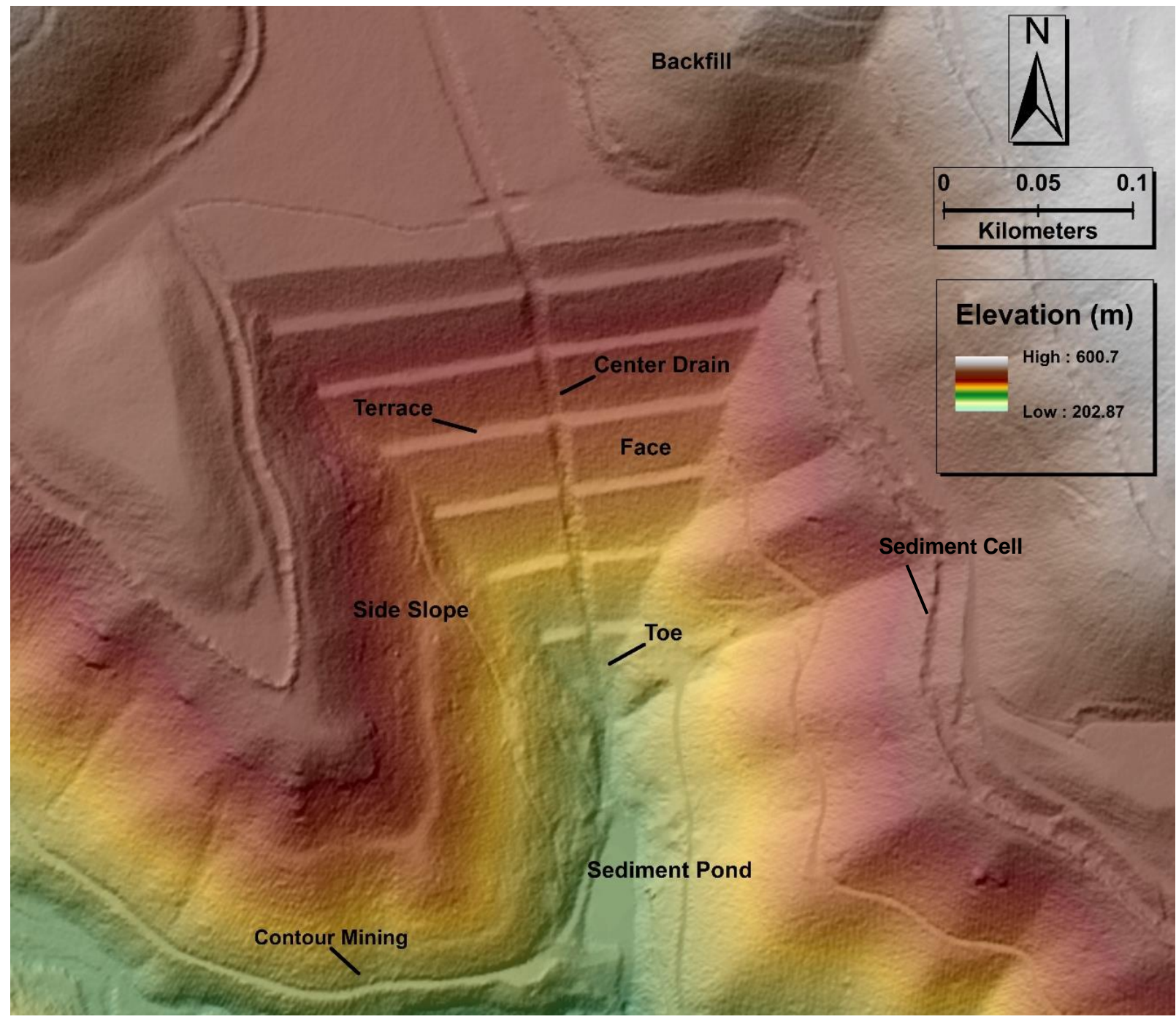


- Max volume 200 million $\mathrm{m}^{3}$ (Ross et al., 2016a)

- Geometrically designed with little regard for geomorphic processes

(Schor and Gray, 2007)

- Designed for geotechnical stability (OSM, 2002)

- $~ 7000$ valley fills in Central Appalachian headwaters (EPA, 2011)

Ben Creek Watershed, Mingo County, West Virginia

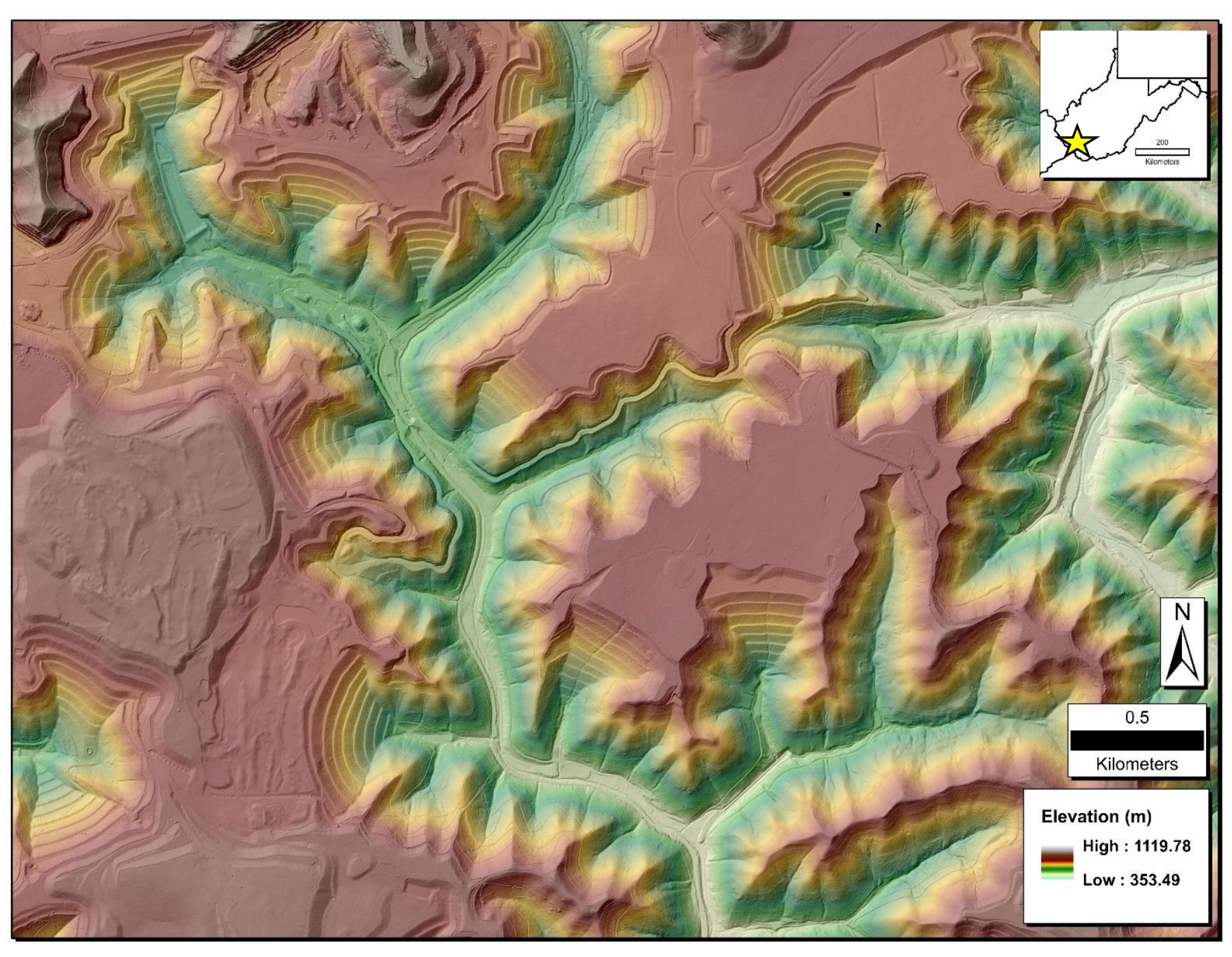




\section{Recent Work}

Unit discharge of unmined and mined catchments with specific conductance. Modified from Nippgen et al., 2017.

Some of highest rates of chemical weathering ever recorded (Ross et al., 2016b)
Electrical resistance tomography cross-section of valley fill in Virginia. Modified from Greer et al., 2017.
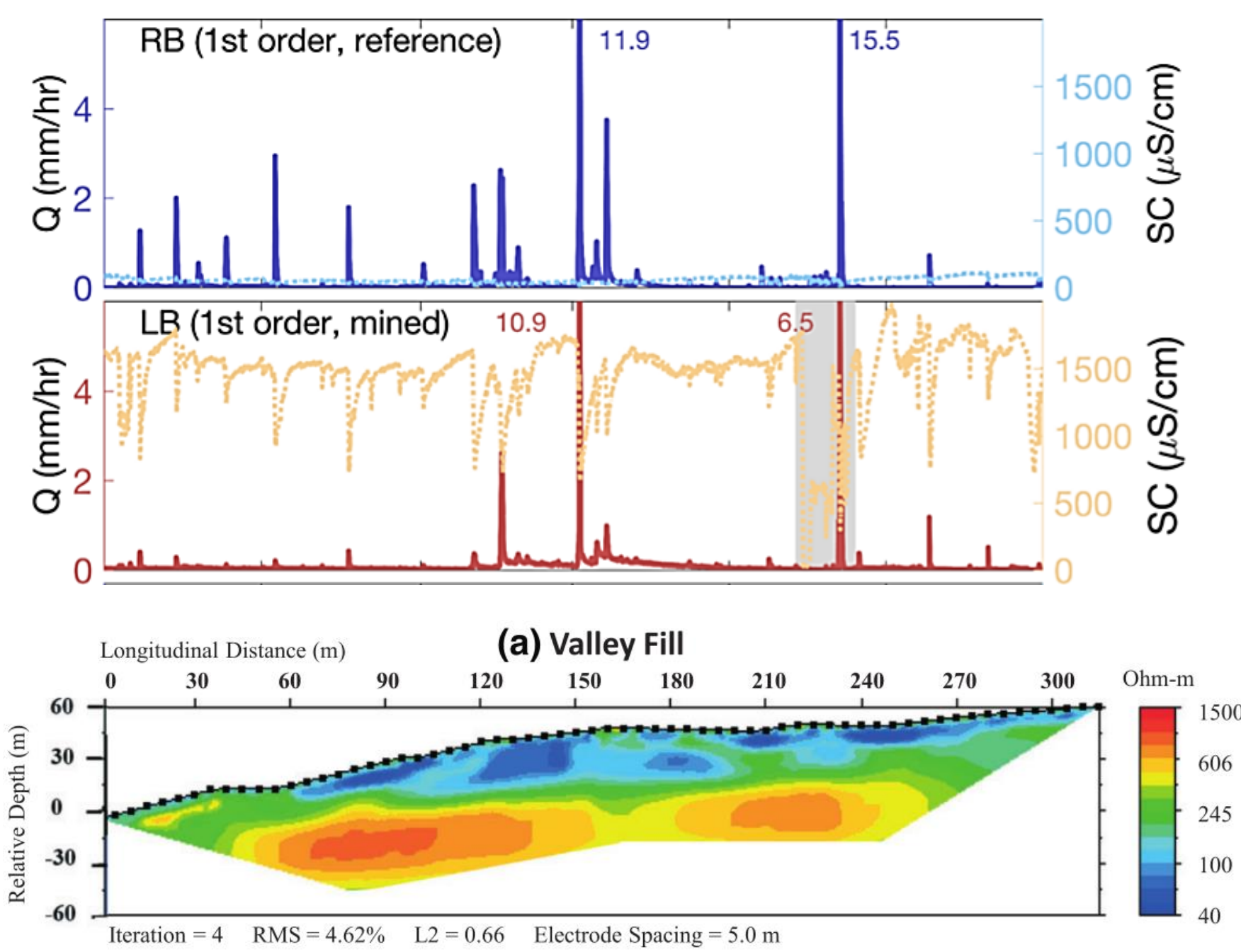


\section{Questions}

- What erosional processes are currently active?

- How will these large, unconsolidated deposits evolve?

\section{Importance}

- Aggradation downstream of valley fills would degrade aquatic ecosystems and increase flooding risk

- No guidance from government or industry on landscape evolution

- Increase understanding of "no-analog" anthropogenic landscapes

- No known field work ever published in geomorphic literature

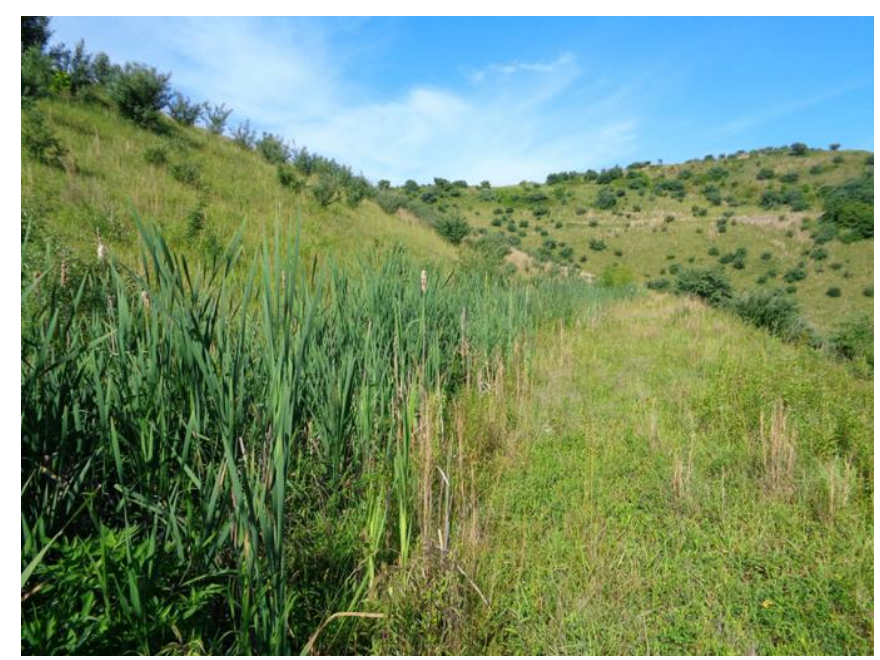




\section{Field Study Areas}

- West Virginia Division of Natural Resources (WVDNR) Wildlife Management Areas (WMAs)

- Middle Pennsylvanian sandstone, siltstone, shale and coal

- Measure erosional landforms on valley fill faces and altered side slopes

- Parameterize the CAESARLisflood Landscape Evolution Model

(Coulthard et al., 2013)

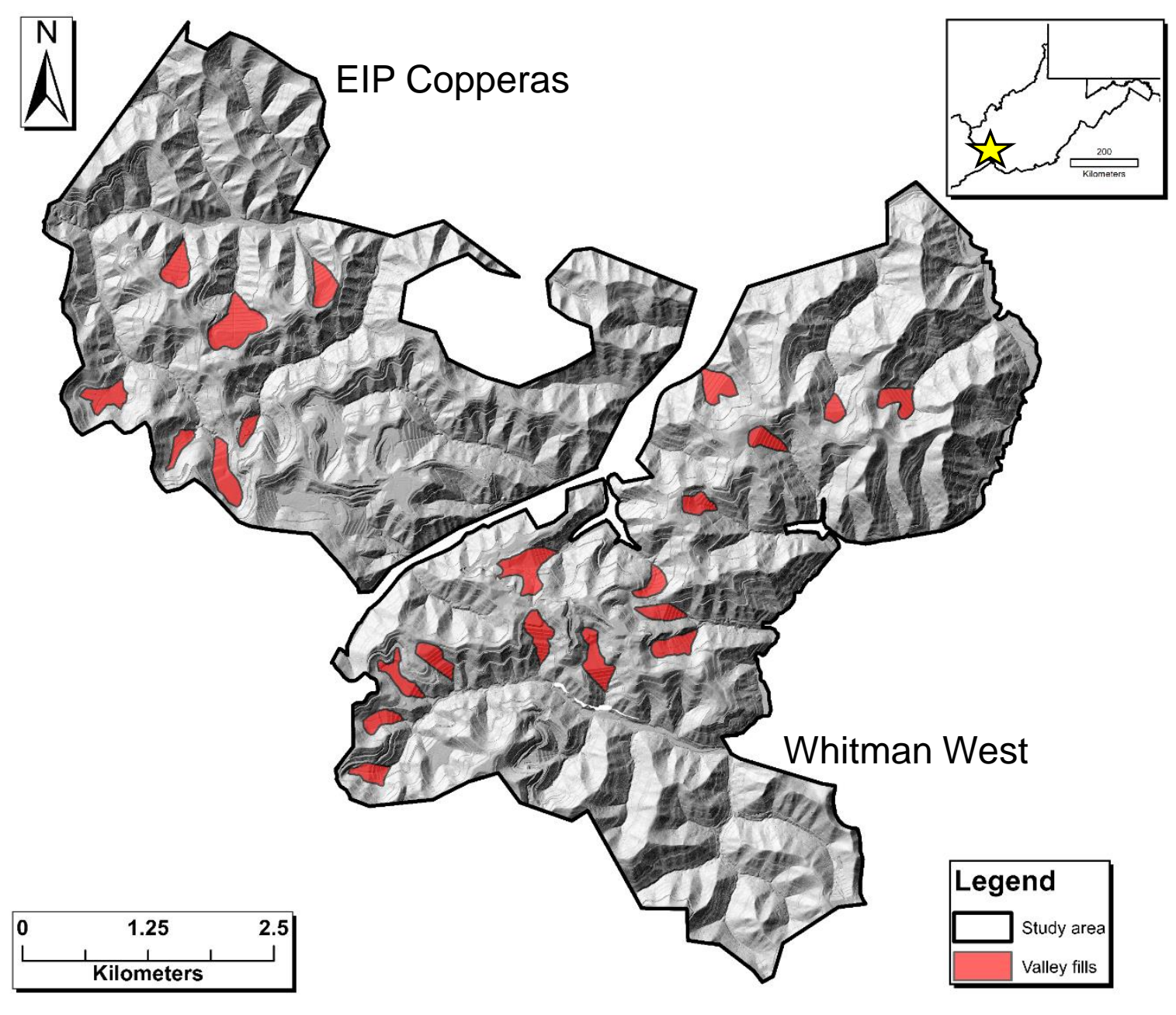


Valley fill 5, EIP Copperas Constructed 2003

$1 \mathrm{~m}$ Lidar slopeshade

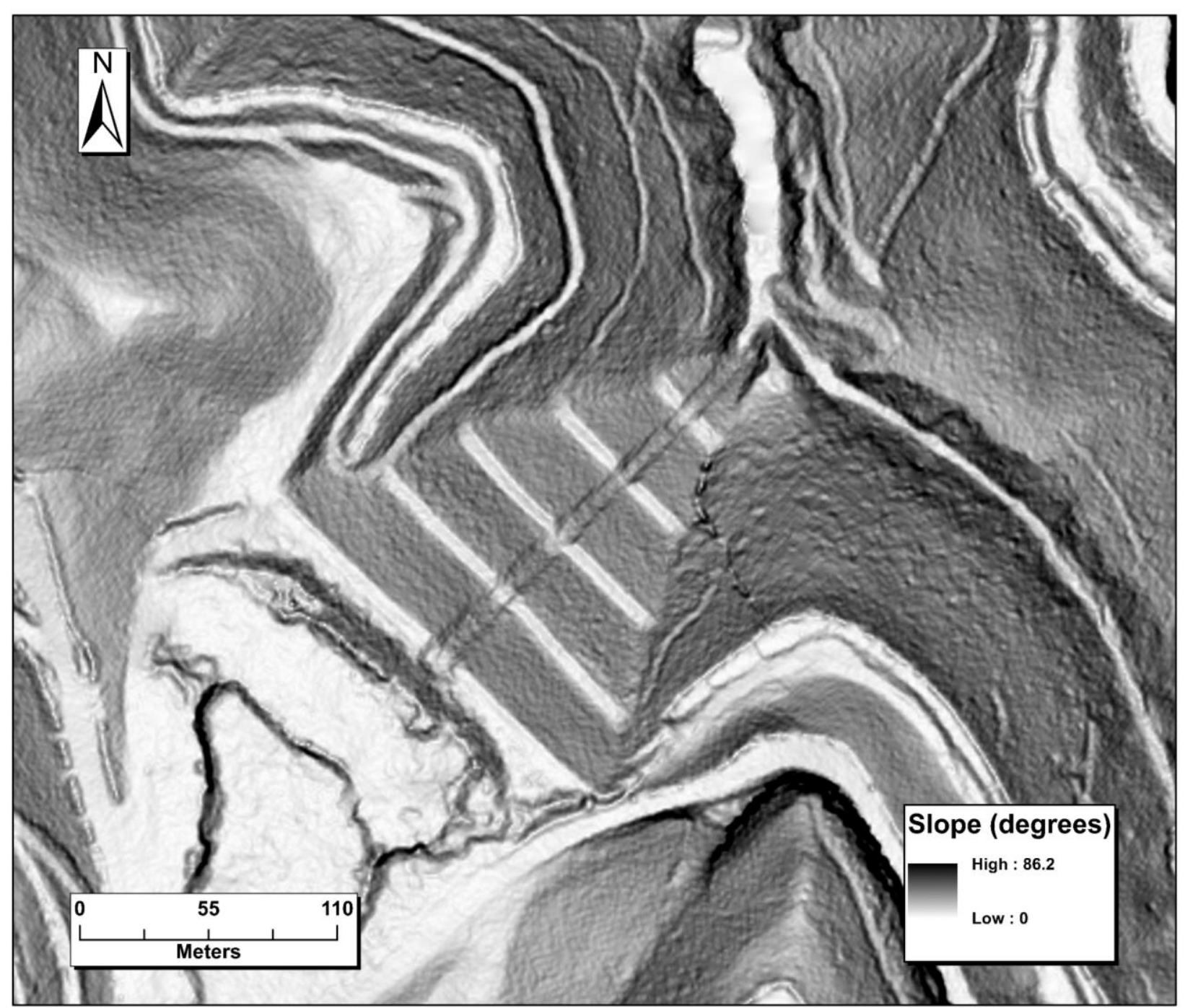


Valley fill 5, EIP Copperas Constructed 2003 1 m Lidar slopeshade
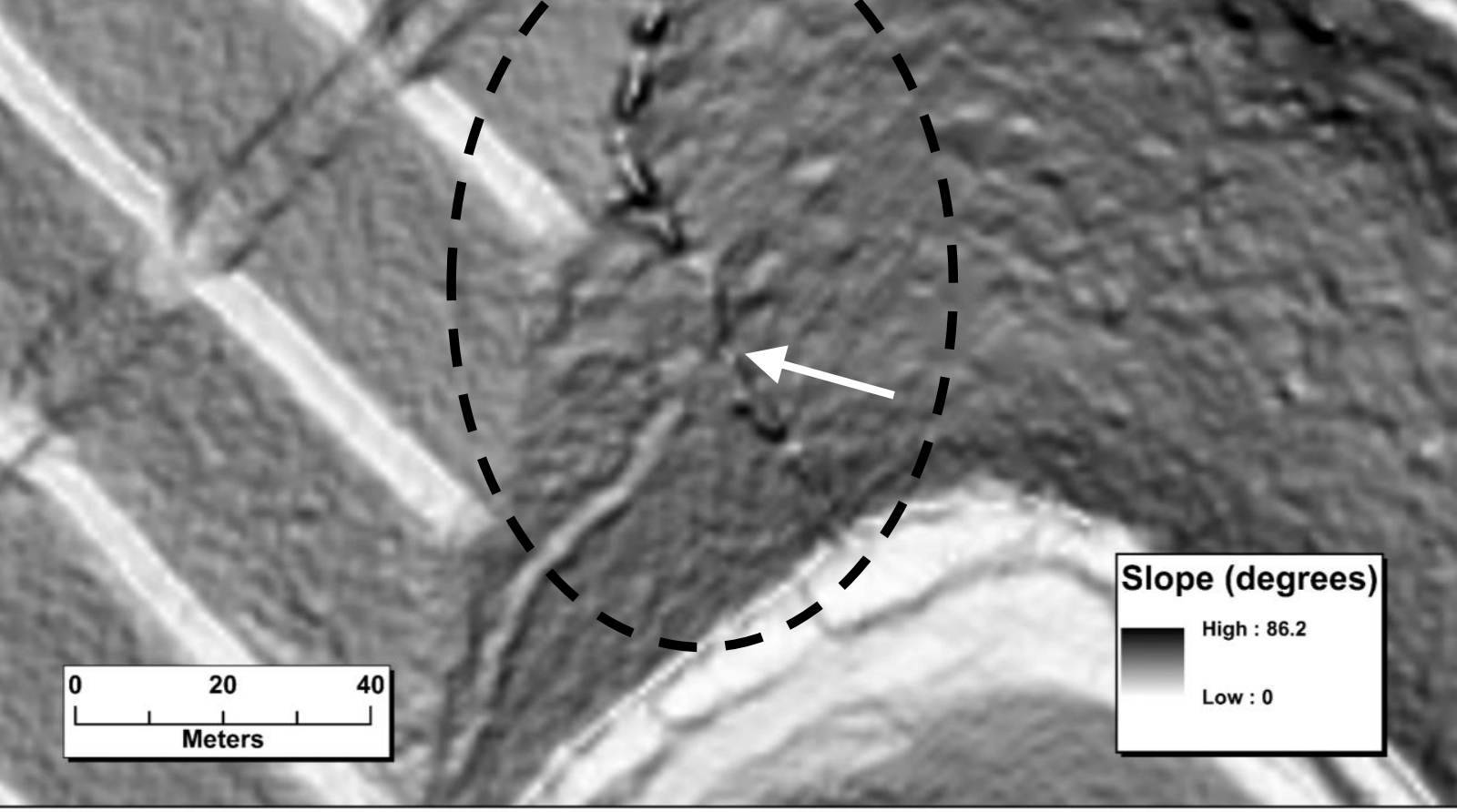
Valley fill 5, EIP Copperas

Downslope view of gully

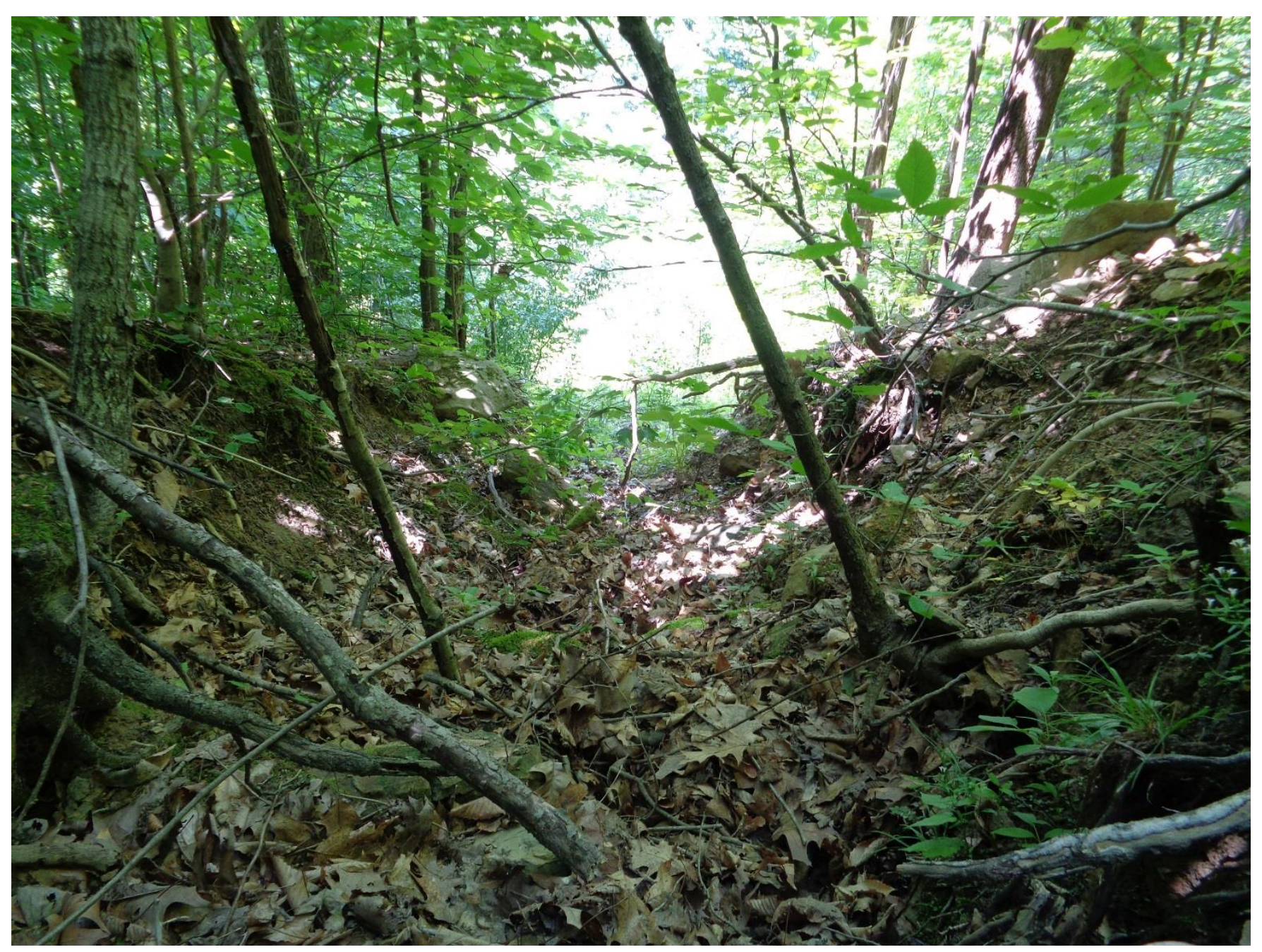


- Large sediment cell along road

- $5 \mathrm{~m}$ wide by $30 \mathrm{~m}$ long by $\sim 1 \mathrm{~m}$ deep

- Situated above $\sim 30^{\circ}$ slope with $170 \mathrm{~m}$ relief

Whitman West

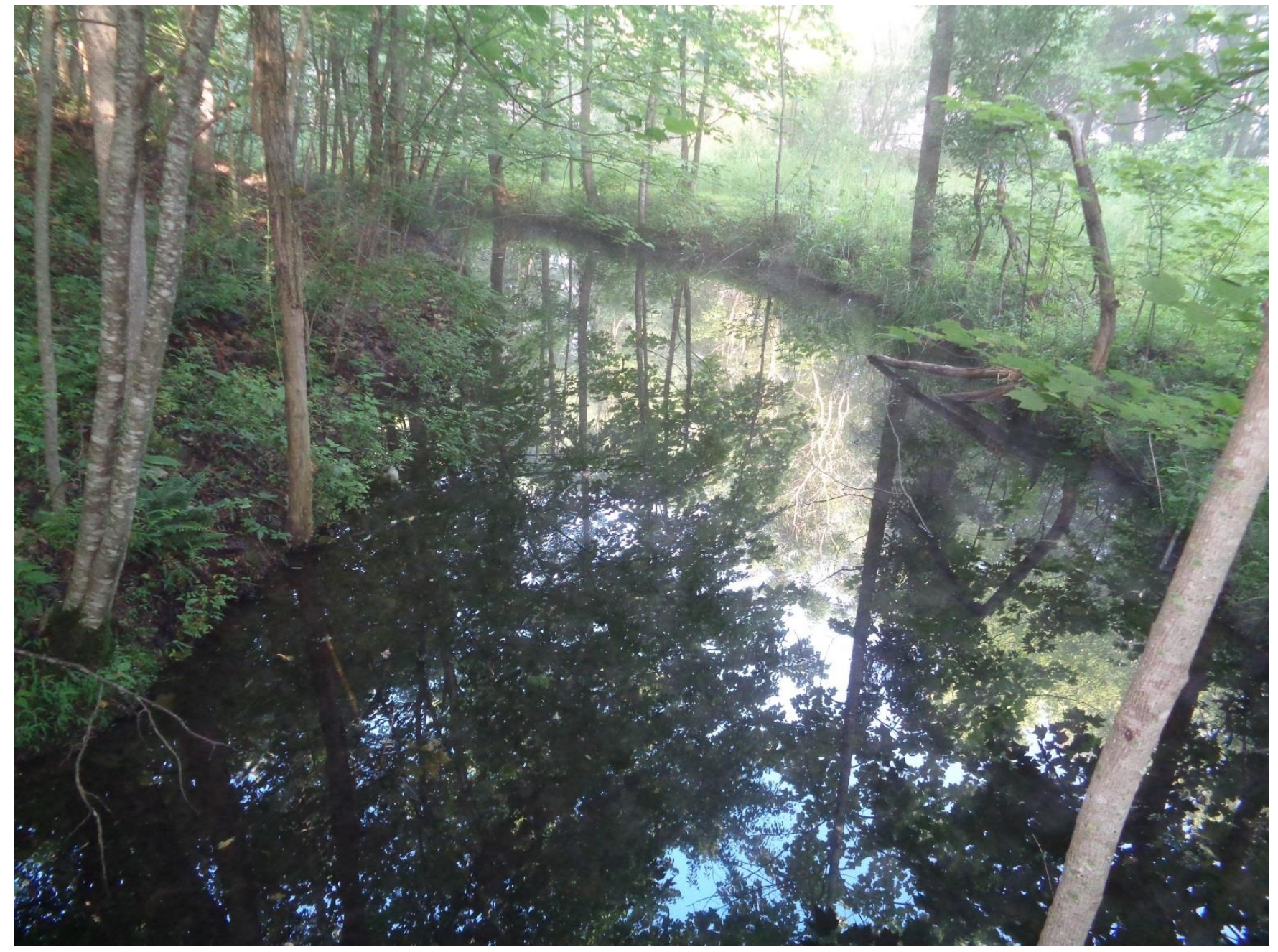



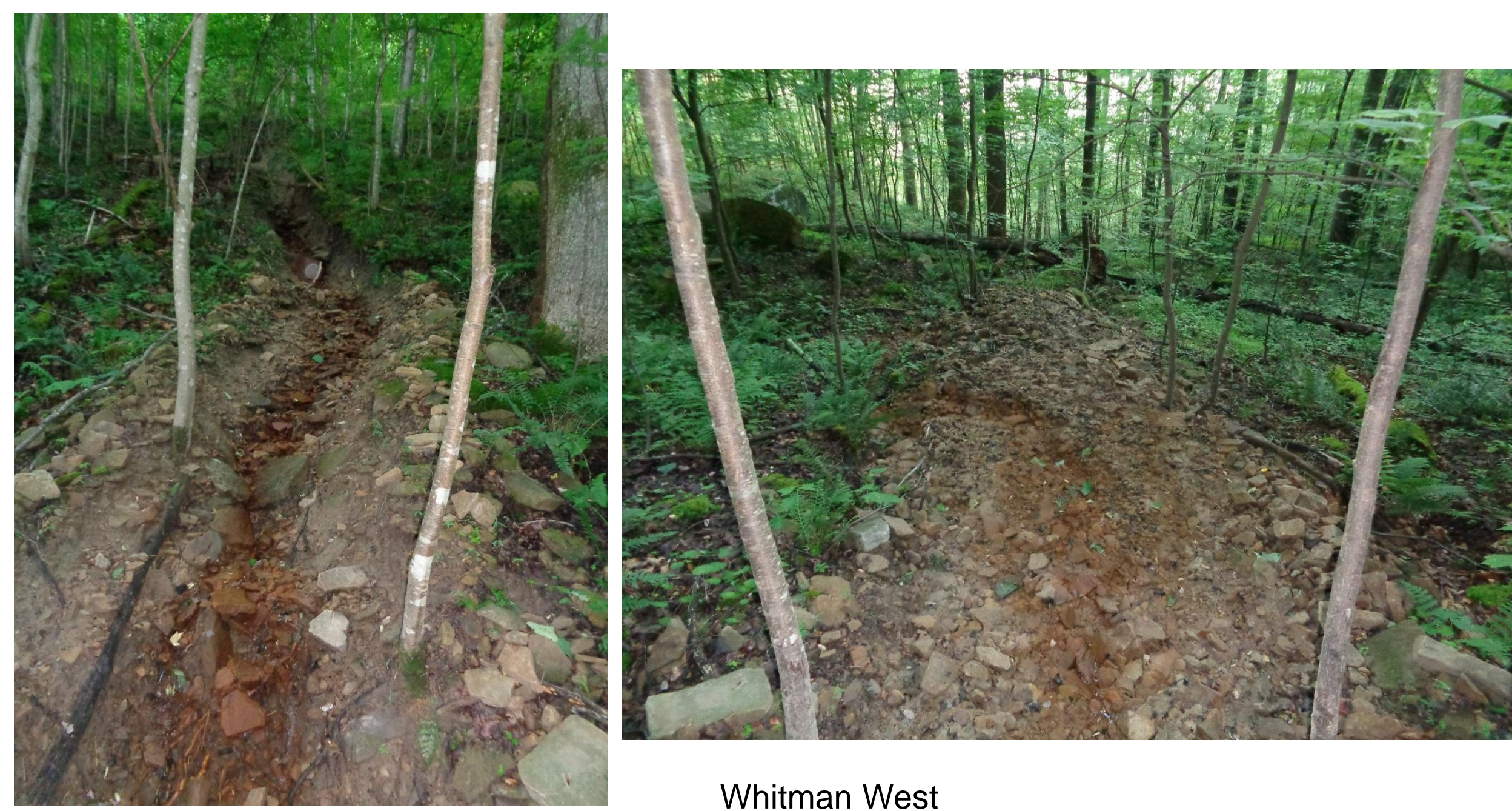

Whitman West 
Valley fill 15, Whitman West Constructed 2003 $1 \mathrm{~m}$ lidar slopeshade

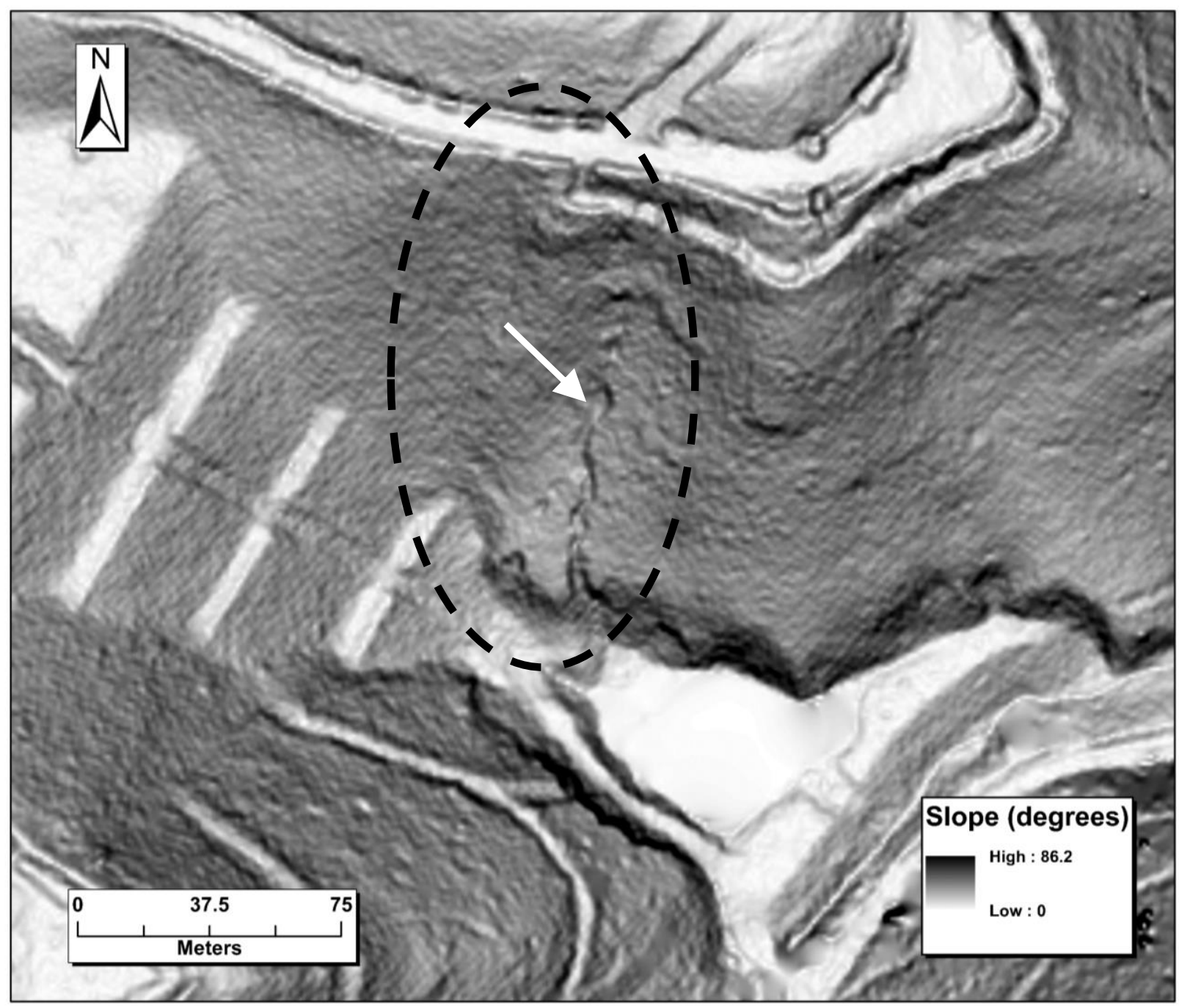




\section{CAESAR-Lisflood Landscape Evolution Model}

(Coulthard et al., 2013)

- A numerical model that changes input topography based on earth surface processes over time

(Hancock and Tucker, 2010)

- Used in reclaimed mining landscapes previously

(Hancock et al., 2015)

- Rainfall -> TOPMODEL runoff $->$ Lisflood hydrodynamics -> Wilcock and Crowe sediment transport model

(Beven and Kirkby, 1979; Bates et al., 2010; Wilcock and Crowe, 2003)

- Outputs of water flow, sediment transport (total and individual grain sizes), and rasters of elevation change and median grain size

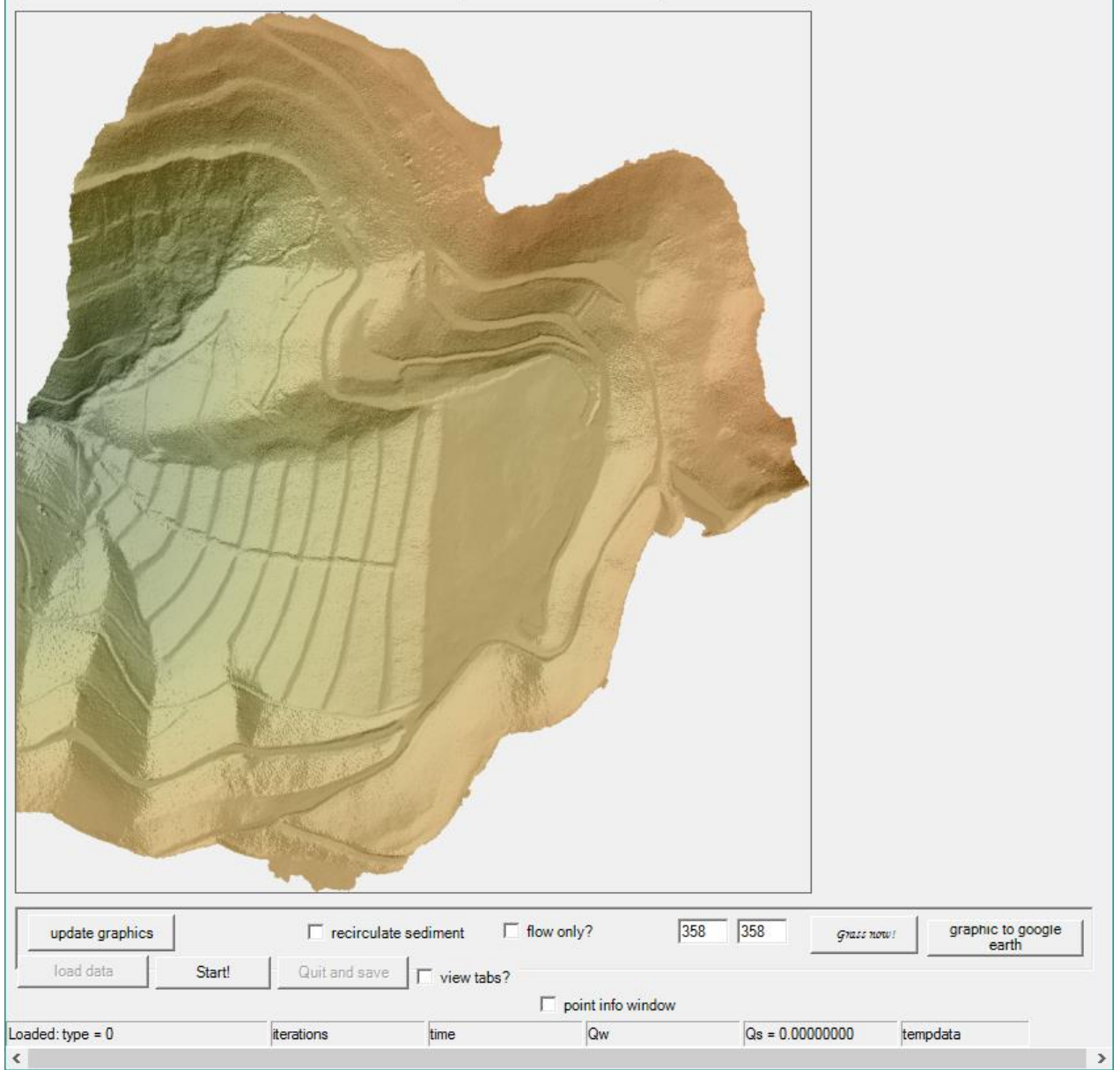




\section{CAESAR-Lisflood test catchment}

- $0.20 \mathrm{~km}^{2}$ catchment

- NOAA hourly rainfall from Charleston, WV run through Neyman-Scott Rectangular Pulse model

(Cowpertwait et al., 1996; Brocca et al., 2013)

- Grain size distributions from field work, soil survey data, and a mining engineering technique used in Jackson (2015)

Valley fill 11, Whitman West

$1 \mathrm{~m}$ lidar hillshade 
- Failure of one sediment cell

- Deposition in other sediment cells

- Development of small fans above each terrace

- Erosion mainly contained to drainage system

\section{Digital elevation model of difference}

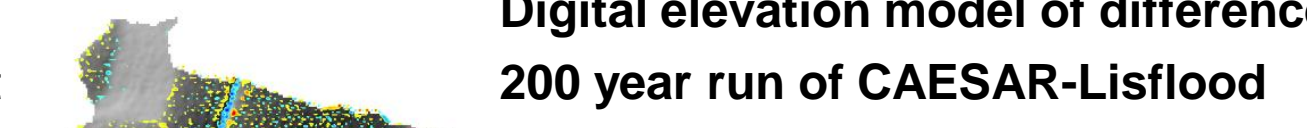

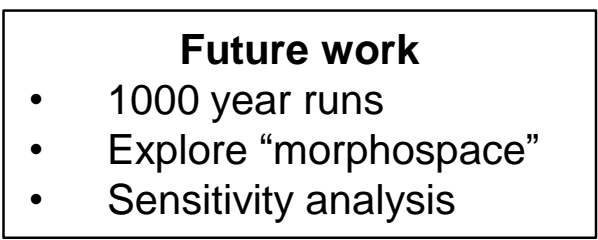

\begin{tabular}{|l|}
\hline Elevation change $(\mathrm{m})$ \\
\hline-0.40 to -1.80 \\
-0.30 to -0.39 \\
\hline$\quad-0.20$ to -0.29 \\
\hline$\quad-0.10$ to -0.19 \\
\hline$\quad-0.09$ to 0.09 \\
\hline$\quad 0.10$ to 0.19 \\
\hline$\quad 0.20$ to 0.29 \\
0.30 to 0.39 \\
\hline 0.40 to 2.08 \\
\hline
\end{tabular}


- What's wrong with Kentucky?

- No failures of this magnitude observed in West Virginia

- Geological?

Pike County, Kentucky

Lidar available from kygeonet.ky.gov

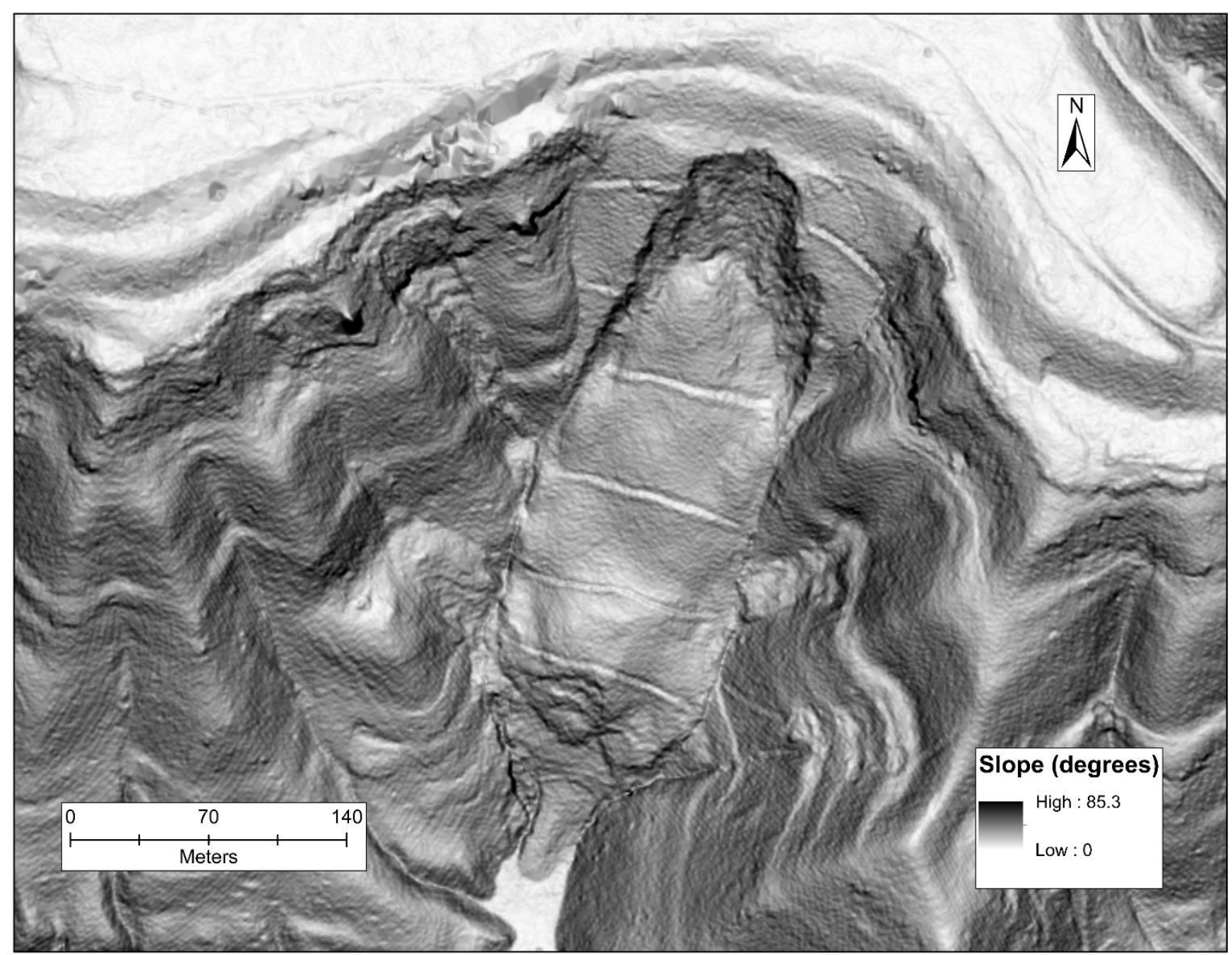


- What's wrong with Kentucky?

- No failures of this magnitude observed in West Virginia

\section{- Geological?}

Pike County, Kentucky

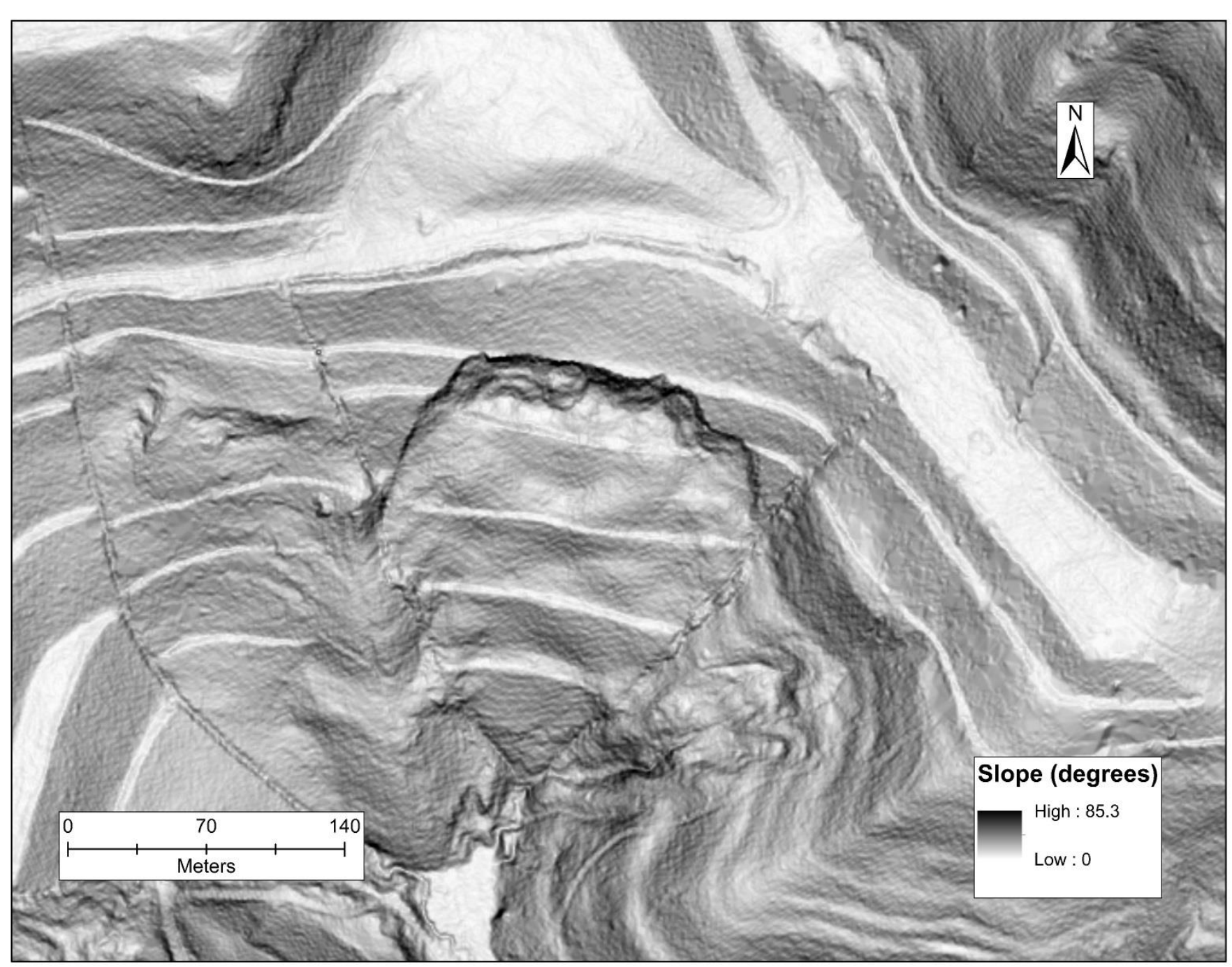




\section{Takeaways}

- Valley fills produced by mountaintop removal are currently eroding via gullying and mass wasting

- Sediment cells above valley fill side slopes can be a pathway to severe erosion from overtopping and intentional routing of flow

- Valley fills are extensive, anthropogenic landforms of known age in areas with extensive lidar coverage (KY and WV)

Thank you. Questions? 


\section{References}

Bates, P. D., Horritt, M. S., and Fewtrell, T. J. (2010). A simple inertial formulation of the shallow water equations for efficient two-dimensional flood inundation modelling. Journal of Hydrology, $387(1)$, 33-45.

Beven, K. J., and Kirkby, M. J. (1979). A physically based, variable contributing area model of basin hydrology. Hydrological Sciences Journal, $24(1), 43-69$.

Brocca, L., Liersch, S., Melone, F., Moramarco, T., and Volk, M. (2013). Application of a model-based rainfall-runoff database as efficient tool for flood risk management. Hydrology and Earth System Sciences, 17(8), 3159-3169.

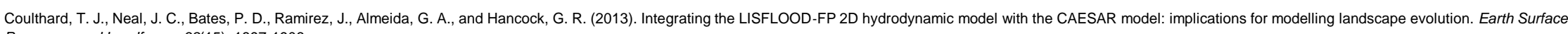
Processes and Landforms, 38(15), 1897-1906.

Cowpertwait, P. S. P., O'Connell, P. E., Metcalfe, A. V., and Mawdsley, J. A. (1996). Stochastic point process modelling of rainfall. I. Single-site fitting and validation. Journal of Hydrology, 175(1-4), 17-46.

Greer, B. M., Burbey, T. J., Zipper, C. E., and Hester, E. T. (2017). Electrical resistivity imaging of hydrologic flow through surface coal mine valley fills with comparison to other landforms. Hydrological Processes.

Hancock, G. R., Lowry, J. B. C., and Coulthard, T. J. (2016). Long-term landscape trajectory-Can we make predictions about landscape form and function for post-mining landforms?. Geomorphology, 266, 121-132.

Jackson, B.M. (2015). TOTAL COST OPTIMIZATION FOR CONTOUR BLASTING IN THE APPALACHIA REGION. Theses and Dissertations--Mining Engineering. http://uknowledge.uky.edu/mng etds/20

Michael, P. R., and M. J., Uranowski. (2010). Challenges to applying geomorphic and stream reclamation methodologies to mountaintop mining and excess spoil fill construction in steep-slope topography (eg Central Appalachia).

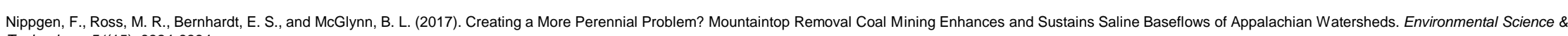
Technology, 51(15), 8324-8334.

Ross, M. R., McGlynn, B. L., and Bernhardt, E. S. (2016a). Deep impact: Effects of mountaintop mining on surface topography, bedrock structure, and downstream waters. Environmental science \& technology, 50(4), 2064-2074.

Ross, M. R., Nippgen, F., Hassett, B., McGlynn, B. L., and Bernhardt, E. S. (2016b). Melting mountains of Appalachia: exceptionally high weathering rates in mined watersheds. In AGU Fall Meeting Abstracts.

Schor, H. J., and Gray, D. H. (2007). Landforming: An Environmental Approach to Hillside Development, Watershed Restoration, and Mine Reclamation.

Tucker, G. E., and Hancock, G. R. (2010). Modelling landscape evolution. Earth Surface Processes and Landforms, 35(1), 28-50.

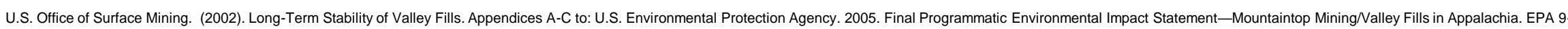
03-R-00013. EPA Region 3, Philadelphia, PA. 49 pp. plus appendices

US Environmental Protection Agency (EPA). (2011). The Effects of Mountaintop Mines and Valley Fills on Aquatic Ecosystems of the Central Appalachian Coalfields; US EPA: Washington, DC, USA.

Wilcock, P. R., and Crowe, J. C. (2003). Surface-based transport model for mixed-size sediment. Journal of Hydraulic Engineering, 129(2), 120-128. 



\section{1h Duration}

- Charleston, West Virginia rainfall from NOAA then run through Neyman-Scott Pulse Model, a rainfall generator

(Brocca et al., 2013)

- Allows for realistic large return interval rainfall events not contained in original record

12h Duration
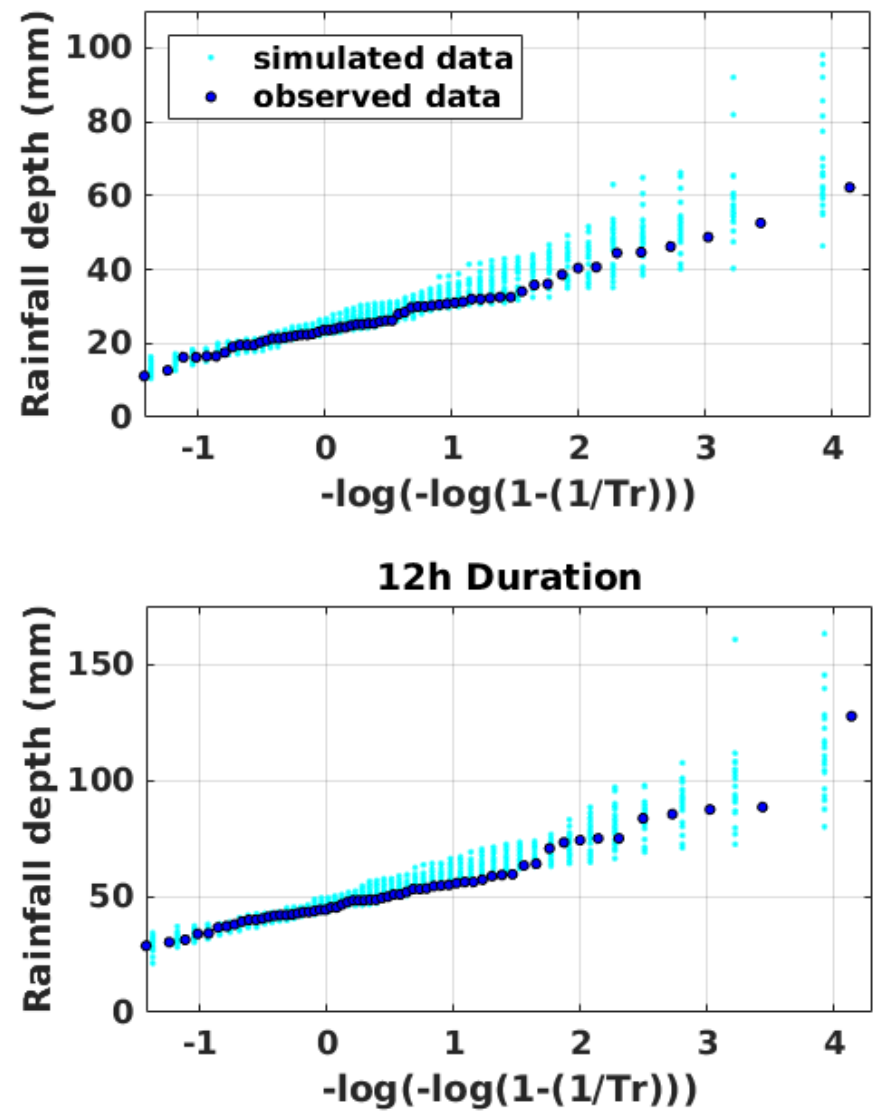

6h Duration
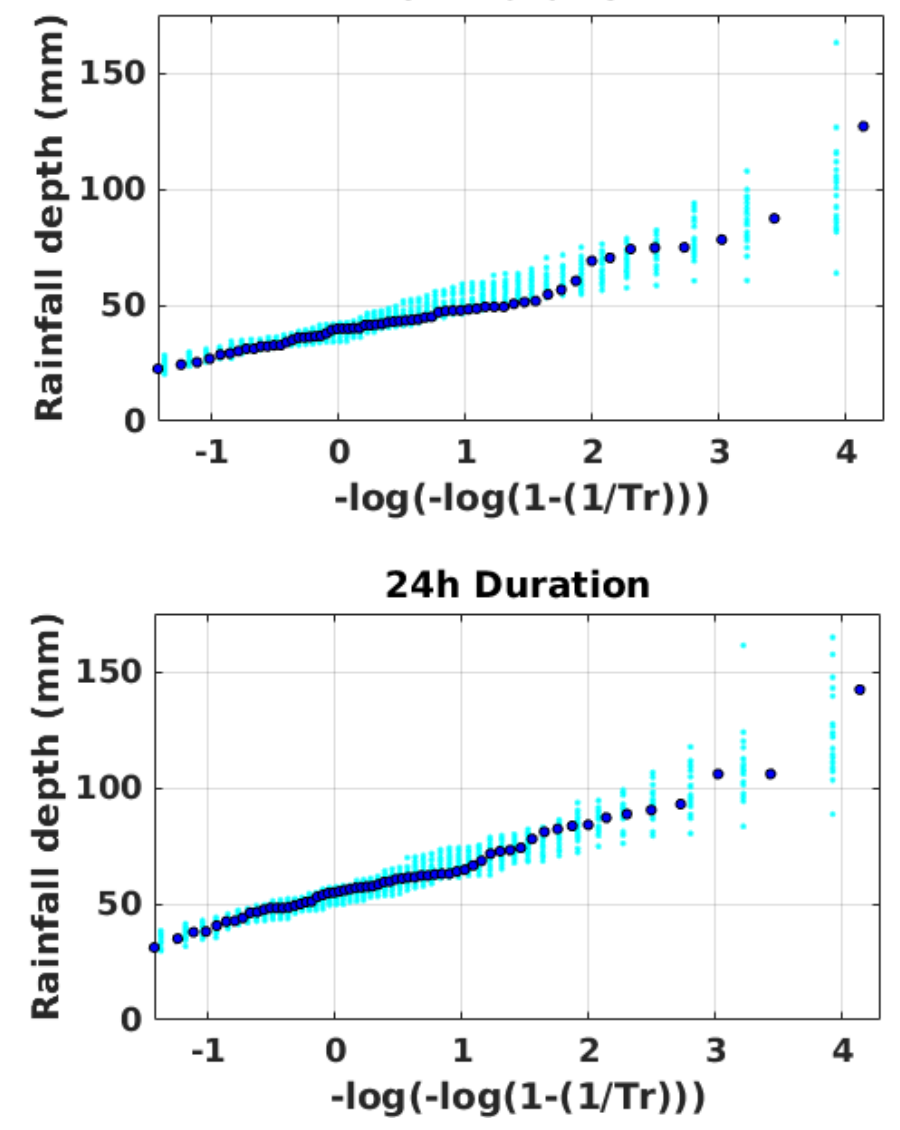


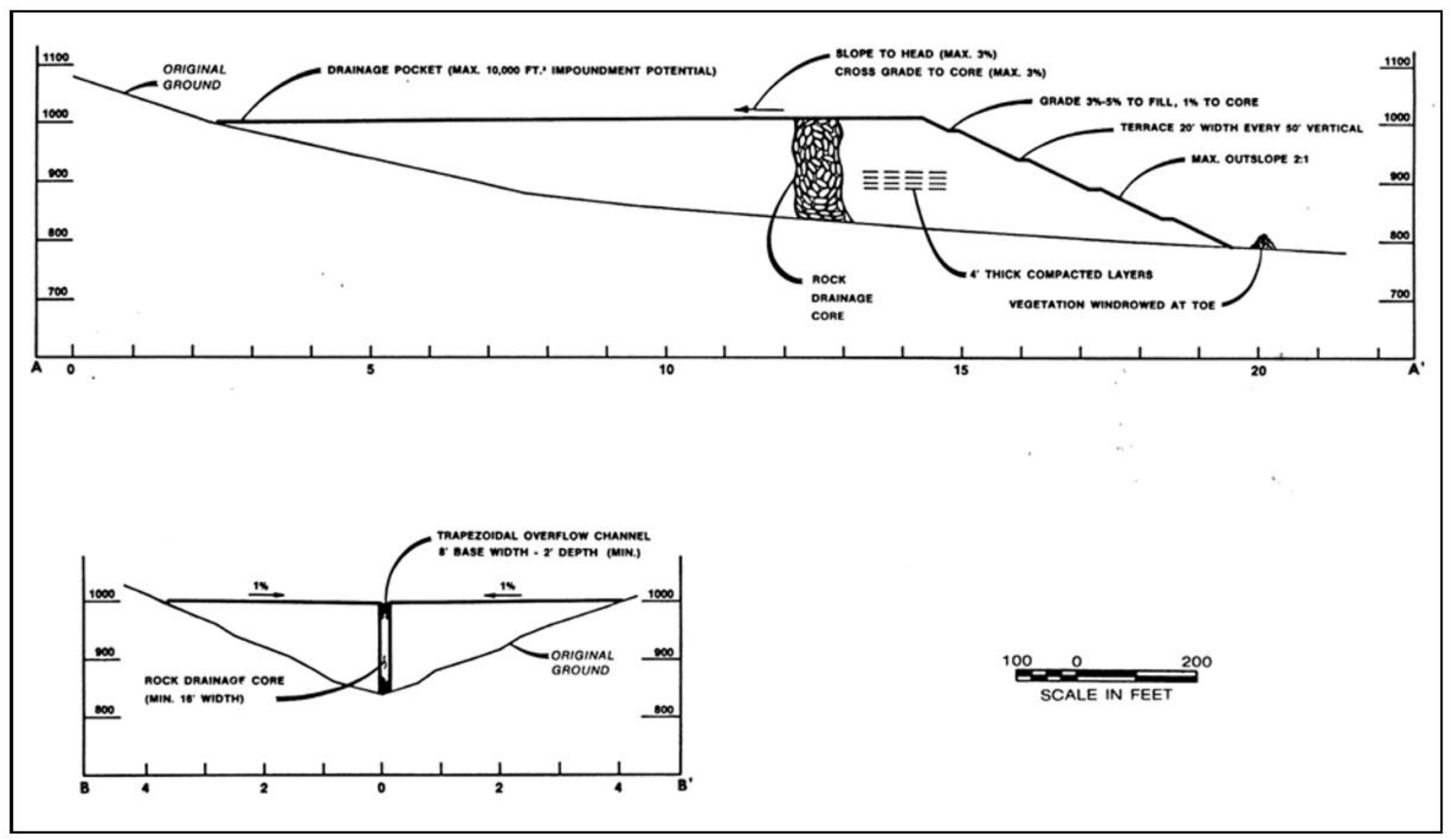



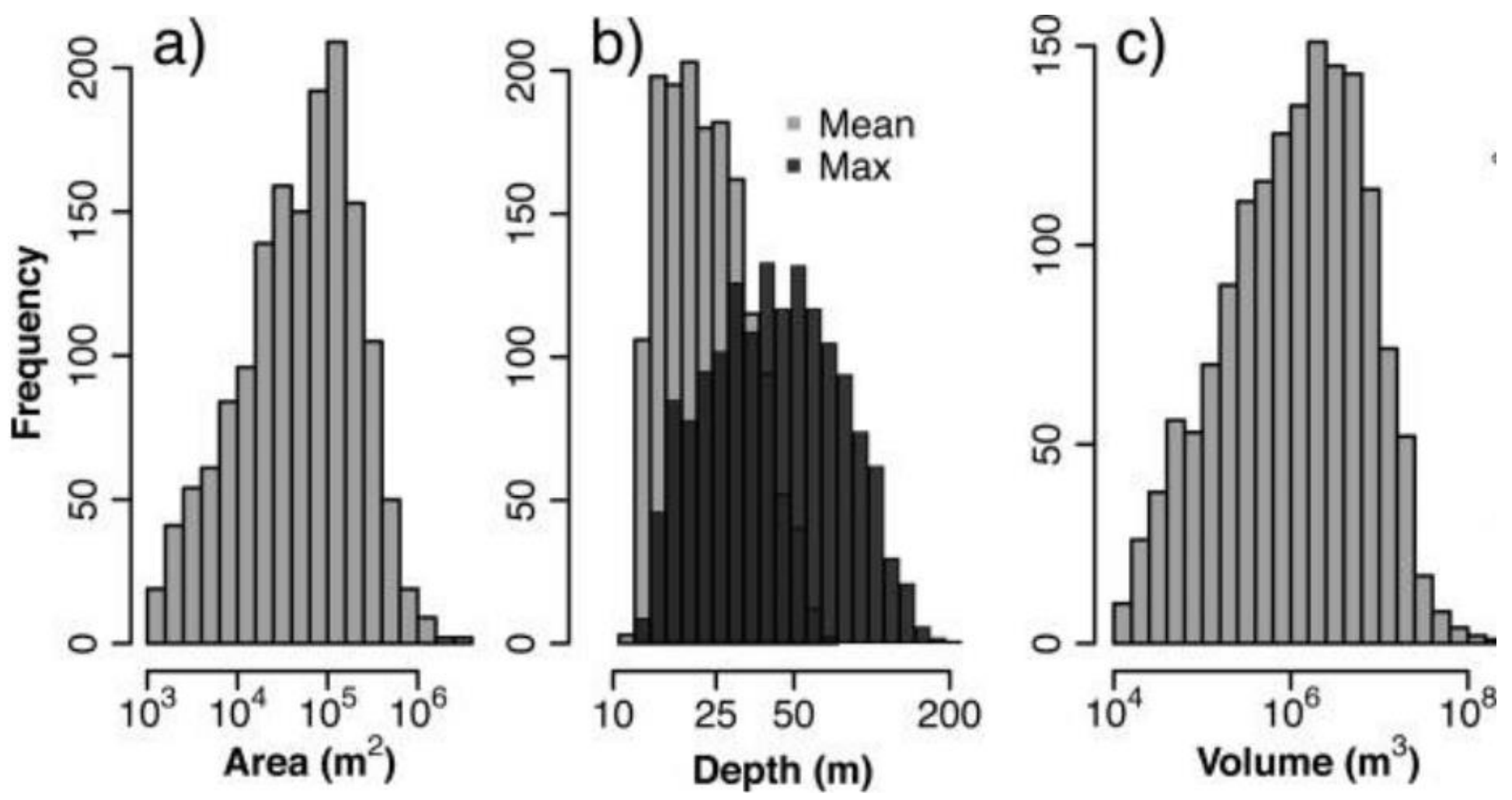

Stats on 1544 West Virginian valley fills. Modified from Ross et al., 2016 